\title{
The prevalence of Mycobacterium tuberculosis using Gene Xpert among tuberculosis suspected patients in Gedeo Zone, Southern Ethiopia
}

\author{
Kuma Diriba $^{1 *}$ (D) and Gemechu Churiso ${ }^{2}$
}

\begin{abstract}
Background: Tuberculosis (TB) is a communicable disease remains a major global health problem and the leading cause of death from a single infectious agent. Even though many of the WHO recommended TB control strategies were implemented; there is still a major gap in TB case detection and treatment. This study aimed to determine the prevalence of Mycobacterium tuberculosis among presumptive TB patients in Gedeo Zone, Southern Ethiopia.

Methods: A cross-sectional study was conducted on 384 TB suspected patients in Gedeo Zone from February to July 2021. Data were collected using a pretested structured questionnaire. Laboratory examination was processed using Xpert-MTB/RIF assay. Data entry was made using Epi info version 7 and analyzed by SPSS version 24. Logistic regression models were used to determine the risk factors.

Results: Out of 384 study participants suspected with TB, M. tuberculosis was isolated from 103 giving an overall prevalence of 26.8\%. Males (AOR) $=1.95 ; 95 \% \mathrm{Cl} 1.56-2.65, P=0.01$ ) were more likely to develop TB than females. Study participants who were illiterate (AOR $2.10 ; 95 \% \mathrm{Cl} 1.17-2.51, P=0.014)$ were more likely to develop TB than the educated ones. Cigarette smokers (AOR 2.89; 95\% Cl 2.10-3.84, $P=0.01$ ), khat chewers (AOR 2.86; 95\% Cl 1.28-3.79, $P=0.01$ ), vaccination (AOR $0.52 ; 95 \% \mathrm{Cl} 0.21-0.88, P=0.02$ ), close contact (AOR $3.42 ; 95 \% \mathrm{Cl} 2.24-4.50, P=0.01$ ) and being positive for HIV (AOR 2.01; 95\% Cl 1.07-3.52, 0.01) were more likely to develop TB.

Conclusion: Despite implementation of national and international TB control strategies, TB still remains one of the major public health problems in the country especially in the study area. The high prevalence of MTB was reported different risk groups. Early case detection and management of TB should be given special attention to strengthen and an appropriate control and prevention methods to reduce the emergence and increasing of MTB cases.
\end{abstract}

Keywords: Presumptive TB, MTB, Xpert-MTB/RIF assay, Ethiopia

\section{Background}

Tuberculosis is an airborne disease resulting from $M$. tuberculosis. TB can affect anyone anywhere. It typically affects the lungs and cause pulmonary TB [1].

*Correspondence: kumadiriba47@gmail.com

${ }^{1}$ Department of Medical Laboratory Sciences, Health Science and Medical College, Dilla University, Dilla, Ethiopia

Full list of author information is available at the end of the article
The World Health Organization (WHO) recently announced that TB remains a major global health problem causing deaths among millions of people each year. $\mathrm{TB}$ is the ninth leading cause of death worldwide and the leading cause from a single infectious agent. Globally, TB kills almost three people every minute [2]. Globally, an estimated 10.0 million people fell ill with $\mathrm{TB}$ and 1.2 million died from the disease $[2,3]$. TB original author(s) and the source, provide a link to the Creative Commons licence, and indicate if changes were made. The images or other third party material in this article are included in the article's Creative Commons licence, unless indicated otherwise in a credit line to the material. If material is not included in the article's Creative Commons licence and your intended use is not permitted by statutory regulation or exceeds the permitted use, you will need to obtain permission directly from the copyright holder. To view a copy of this licence, visit http://creativecommons.org/licenses/by/4.0/. The Creative Commons Public Domain Dedication waiver (http://creativeco mmons.org/publicdomain/zero/1.0/) applies to the data made available in this article, unless otherwise stated in a credit line to the data. 
mortality and incidence rate are falling at about $3 \%$ and $2 \%$ per year worldwide, respectively $[4,5]$.

According to the WHO report of 2019, more than 95\% of TB deaths occurred in low and middle-income countries. Poverty may result in poor nutrition, which may be associated with alterations in immune function. It also results in overcrowded living conditions, poor ventilation, and poor hygiene habits which are likely to increase the risk of transmission of TB [6, 7]. WHO has been targeting an end TB strategy based on an assessment of the TB epidemic and progress in TB diagnosis, treatment, and prevention efforts. This shift in the approach to TB control, which includes among its 2030 targets (90\% TB case detection and treatment) including in high-risk populations, and a cure rate of $90 \%$ of detected TB cases [8].

In Ethiopia various efforts have been made to control TB since TB was recognized as a major public health problem [4]. Despite all these national and international efforts, TB still remains one of the major public health problems in the country [5]. The recommended strategy to control TB in low income countries including Ethiopia, where $95 \%$ of the TB cases occur, is to detect and promptly treat smear-positive cases. It is known that delayed diagnosis results in more extensive disease, more complications and leads to a higher mortality. It also leads to an increased period of infectivity in the community [9].

Tuberculosis is exclusively transmitted based on environmental and personal associated risk factors $[10,11]$. The risk factors contributing to acquiring TB infection are social and behavioral risk factors that include smoking, alcohol, khat chewing, and indoor air pollution [12]. Co-morbidities (people with certain chronic diseases) like diabetes, cancer, and HIV that affect the immune defenses system, close contact with active pulmonary TB patients, intravenous drug abuse, patients receiving immunosuppressive therapies and health care workers are those peoples at high risk of acquiring the TB infection [13-15].

The early diagnosis and treatment of TB patients is mandatory to reduce transmission of the disease. Millions of people are diagnosed and successfully treated for TB each year, averting millions of deaths, but there are still large gaps in detection and treatment. For the application of control policy, efforts for the identification of TB cases and treatment are mandatory which is not currently sufficient. As a result of this, updated knowledge of the prevalence of M. tuberculosis and their associated factor are crucial. Hence, the present study was intended to provide updated information on the prevalence of pulmonary tuberculosis and associated factor at Gedeo Zone, Southern Ethiopia.

\section{Methods}

\section{Study design and study area}

A cross-sectional study design was conducted from February to July 2021 in Gedeo Zone, Southern Ethiopia. The study populations were all pulmonary $\mathrm{TB}$ suspected patients who visited the selected health institution during the study period.

The study was conducted in Gedeo zone, which is located at southern direction of Ethiopia with a total estimated population of $1,694,868$ according to the 2007 population census conducted by the Central Statistical Agency of Ethiopia (data are from Zonal health office). Gedeo Zone is found at a distance of $85 \mathrm{~km}$ from Hawasa and $365 \mathrm{~km}$ far from Addis Ababa, the capital city of Ethiopia. It is located in kola agro ecological zone with an altitude of $1400 \mathrm{~km}$ above sea level and annual temperature ranging from 22 to $29^{\circ} \mathrm{C}[16]$.

\section{Study population}

The study populations were all pulmonary TB suspected patients of age $\geq 18$ who visited the selected health institution during the study period. The inclusion criteria were all PTB suspected patients of age $\geq 18$ years. The diagnosis of the patients was done by experienced physician and suspected cases for pulmonary TB with clinical manifestation of cough for two or more weeks, chest pain, or pain with breathing or coughing, night sweats, weight loss, fatigue, fever, chills, known or possible TB exposure were sent to laboratory for confirmation. The exclusion was patients with age $<18$ years and study subjects who were unable to give informed consent were excluded.

\section{Sample size and sampling technique}

The sample sizes was calculated using a single population proportion formula by taking the prevalence of $M$. tuberculosis (30.5\%) conducted in Hawasa, 5\% margin of error $(d=0.05)$ and $95 \%$ confidence interval $(z=1.96)$. The initial sample size was 349 , and by considering a $10 \%$ nonresponse rate, the final sample size was determined to be 384 .

\section{Data collection laboratory processing}

Socio-demographic characteristics of study participants and clinical features were collected using pre-structured questionnaire and relevant data were collected from each study participant by trained health professionals. Those patients identified with signs and symptoms of pulmonary tuberculosis were ordered to bring a single sputum sample for the diagnosis of TB using XpertMTB/RIF assay (Cepheid, CA, USA). Briefly, $2 \mathrm{ml}$ of Gene Xpert MTB/RIF sample reagent buffer was added to $1 \mathrm{ml}$ of sputum specimen using a sterile pipette. The 
closed specimen container was manually agitated twice for $15 \mathrm{~s}$ and allowed to stand at room temperature for $10 \mathrm{~min}$ and again vortexed after $10 \mathrm{~min}$ and allowed to stand for $5 \mathrm{~min}$ and then $2 \mathrm{ml}$ of the inactivated material was transferred to the test cartridge and the cartridge was then loaded into Gene Xpert device. Finally, the results were interpreted by the Gene Xpert diagnosis system from the measured fluorescent signals and displayed automatically after $2 \mathrm{~h}$. Rapid HIV test was done according to the national HIV test algorithm [17].

\section{Data processing and analysis}

After all demographic data and patients' history were collected from the registration book; data entry, data analysis and data cleaning were done using Epi-Data 3.1 and SPSS version 23.0 software. Frequency count and percentage were used to present the findings. Prevalence figures were calculated for the total study population and separately by clinical features of the disease. Association factors were assessed by binary logistic regression and multivariate logistic regression. $P$-value less than 0.05 were considered statistically significant.

\section{Results}

\section{Socio-demographic and clinical features of study} participants

A total of 384 study participants suspected with TB aged $\geq 18$ years were included in this study, out of which $64.3 \%$ were male and $35.7 \%$ were female with a sex distribution ratio of 1.8:1. The age of the study participants ranged from 18 to 91 years with the median age of 32 (interquartile range 25.7-51.3 years). Most of the study participants were found within the age range of 30-44 (41.6\%). More than half (59.9\%) of the study participants were from high school while those unemployed study participants account $54.9 \%$ (Table 1 ).

\section{Prevalence of MTB and different clinical features}

Out of 384 study participant suspected for TB, M. tuberculosis was isolated from 103 giving an overall prevalence of $26.8 \% .20 .8 \%$ of study participants were smokers of 5 to 11 cigarettes per day while about one-third of study participants (31\%) were khat chewers. In this study, again around one-third of TB suspected cases (32.3\%) reported a history of close contact with known $\mathrm{TB}$, while only $16.1 \%$ of cases reported as they were vaccinated for TB. In the current study, only $7.6 \%$ of study participants reported to be positive for HIV (Table 2).

\section{Analysis of contributing factors for M. tuberculosis}

In bivariable analyses different age groups, residence, marital status, occupation, History of imprisonment and alcohol consumption had not shown an association
Table 1 Socio-demographic characteristics of study participant suspected with TB, Gedeo Zone, 2021 ( $N=384)$.

\begin{tabular}{|c|c|c|c|}
\hline Variables & Categories & Frequency & Percentage (\%) \\
\hline \multirow[t]{2}{*}{ Gender } & Male & 247 & 64.3 \\
\hline & Female & 137 & 35.7 \\
\hline \multirow[t]{4}{*}{ Age categories } & $18-29$ & 81 & 21.1 \\
\hline & $30-44$ & 160 & 41.6 \\
\hline & $45-59$ & 88 & 22.9 \\
\hline & $>60$ & 55 & 14.4 \\
\hline \multirow[t]{3}{*}{ Income } & $<1500$ & 122 & 31.8 \\
\hline & $1500-3000$ & 159 & 41.4 \\
\hline & $>3000$ & 103 & 26.8 \\
\hline \multirow[t]{2}{*}{ Residence } & Rural & 177 & 46.1 \\
\hline & Urban & 207 & 53.9 \\
\hline \multirow[t]{3}{*}{ Marital status } & Single & 206 & 53.6 \\
\hline & Married & 165 & 42.9 \\
\hline & Divorced & 13 & 3.5 \\
\hline \multirow[t]{3}{*}{ Educational level } & Illiterate & 117 & 30.5 \\
\hline & High school or lower & 230 & 59.9 \\
\hline & Collage and above & 37 & 9.6 \\
\hline \multirow[t]{2}{*}{ Occupation } & Employed & 173 & 45.1 \\
\hline & Unemployed & 211 & 54.9 \\
\hline
\end{tabular}

Table 2 Personal life condition and comorbidity data of TB suspected study participants, Gedeo Zone, 2021 ( $N=384)$

\begin{tabular}{|c|c|c|c|}
\hline Variables & Categories & Frequency & Percentage (\%) \\
\hline \multirow[t]{2}{*}{ Smoke } & Yes & 80 & 20.8 \\
\hline & No & 304 & 79.2 \\
\hline \multirow[t]{2}{*}{ Khat chewing } & Yes & 119 & 31.0 \\
\hline & No & 265 & 69.0 \\
\hline \multirow[t]{2}{*}{ Vaccination for BCG } & Yes & 62 & 16.1 \\
\hline & No & 322 & 83.9 \\
\hline \multirow[t]{2}{*}{ MTB result } & Detected & 103 & 26.8 \\
\hline & Not detected & 281 & 73.2 \\
\hline \multirow{2}{*}{$\begin{array}{l}\text { Close contact with } \\
\text { known TB }\end{array}$} & Yes & 124 & 32.3 \\
\hline & No & 260 & 67.7 \\
\hline \multirow[t]{2}{*}{ History of imprisonment } & Yes & 38 & 9.9 \\
\hline & No & 346 & 90.1 \\
\hline \multirow[t]{2}{*}{ Frequent alcohol } & Yes & 42 & 10.9 \\
\hline & No & 342 & 89.1 \\
\hline \multirow{2}{*}{$\begin{array}{l}\text { Status of HIV antibody } \\
\text { test }\end{array}$} & Yes & 29 & 7.6 \\
\hline & No & 355 & 92.4 \\
\hline
\end{tabular}

with developing TB. In this study, males were more likely to develop TB than females (AOR 1.95; 95\% CI 1.562.65). Study participants who had no educational background (AOR 2.10; 95\% CI 1.17-2.51) were more likely to develop TB than the educated one. Cigarette smokers (AOR 2.89; 95\% CI 2.10-3.84), khat chewers (AOR 
2.86; 95\% CI 1.28-3.79), vaccination (AOR 0.52; 95\% CI 0.21-0.88), close contact (COR AOR 3.42; 95\% CI 2.244.50), study participants who were positive for HIV (AOR 2.01; 95\% CI 1.07-3.52) were more likely to develop TB (Table 3).

\section{Discussion}

Data on local epidemiology of MTB and associated risk factors were useful for the prevention and control of

Table 3 Multivariate analysis of contributing factors among patients suspected with TB in Gedeo Zone, 2021 ( N=384)

\begin{tabular}{|c|c|c|c|c|c|c|}
\hline Categories & MTB Pos $N(\%)$ & MTB Neg $N(\%)$ & COR $(95 \% \mathrm{Cl})$ & $P$ value & AOR $(95 \% \mathrm{Cl})$ & $P$ value \\
\hline \multicolumn{7}{|l|}{ Gender } \\
\hline Male & 73(70.9) & 174(61.9) & $1.70(1.43-2.13)$ & $0.045^{*}$ & $1.95(1.56-2.65)$ & $0.01^{*}$ \\
\hline Female & $30(29.1)$ & 107(38.1) & 1 & 1 & 1 & 1 \\
\hline \multicolumn{7}{|l|}{ Age categories } \\
\hline $18-29$ & $22(21.4)$ & $59(21.0)$ & 1 & 1 & 1 & 1 \\
\hline $30-44$ & $42(40.7)$ & $118(42.0)$ & $1.16(0.55-2.46)$ & 0.411 & $1.16(0.55-2.46)$ & 0.401 \\
\hline $45-59$ & $24(23.3)$ & $64(22.8)$ & $1.0(0.51-1.99)$ & 0.213 & $1.0(0.51-1.99)$ & 0.103 \\
\hline$>60$ & 15(14.6) & $40(14.2)$ & $1.05(0.51-2.18)$ & 0.573 & $1.05(0.51-2.18)$ & 0.363 \\
\hline \multicolumn{7}{|l|}{ Residence } \\
\hline Rural & 48(46.6) & $129(45.9)$ & 1 & 1 & 1 & 1 \\
\hline Urban & $55(53.4)$ & $152(54.1)$ & $0.95(0.63-1.46)$ & 0.521 & $0.95(0.63-1.46)$ & 0.421 \\
\hline \multicolumn{7}{|l|}{ Marital status } \\
\hline Single & $55(53.4)$ & $151(53.7)$ & $1.43(0.44-4.63)$ & 0.350 & $1.43(0.44-4.63)$ & 0.350 \\
\hline Married & $44(42.7)$ & $121(43.1$ & $0.73(0.23-2.34)$ & 0.491 & $0.73(0.23-2.34)$ & 0.491 \\
\hline Divorced & $4(3.9)$ & $9(3.2)$ & 1 & 1 & 1 & 1 \\
\hline \multicolumn{7}{|l|}{ Educational level } \\
\hline Illiterate & $32(31.1)$ & $85(30.2)$ & $2.14(1.28-3.59)$ & $0.016^{*}$ & $2.10(1.17-2.51)$ & $0.014^{*}$ \\
\hline High school or lower & $62(60.2$ & 168(59.8) & $1.88(0.83-4.24)$ & 0.131 & $1.36(0.71-4.11)$ & 0.130 \\
\hline Collage and above & $9(8.7)$ & $28(10.0)$ & 1 & 1 & 1 & 1 \\
\hline \multicolumn{7}{|l|}{ Occupation } \\
\hline Employed & $46(44.7)$ & $127(45.2)$ & $1.09(0.72-1.68)$ & 0.311 & $1.09(0.72-1.68)$ & 0.243 \\
\hline Unemployed & $57(55.3)$ & 154(54.8) & 1 & 1 & 1 & 1 \\
\hline \multicolumn{7}{|l|}{ Smoke } \\
\hline Yes & $21(20.4)$ & $59(21.0)$ & $2.23(1.12-3.57)$ & $0.034^{*}$ & $2.89(2.10-3.84)$ & $0.01^{*}$ \\
\hline No & 82(79.6) & $222(79.0)$ & 1 & 1 & 1 & 1 \\
\hline \multicolumn{7}{|l|}{ Khat chewing } \\
\hline Yes & $32(31.1)$ & $87(30.9)$ & $2.66(1.28-3.89)$ & $0.025^{*}$ & $2.86(1.28-3.79)$ & $0.01^{*}$ \\
\hline No & $71(68.9)$ & 194(69.1) & 1 & 1 & 1 & 1 \\
\hline \multicolumn{7}{|l|}{ Vaccination for BCG } \\
\hline Yes & $17(16.5)$ & $45(16.0)$ & $0.35(0.19-0.71)$ & $0.023^{*}$ & $0.52(0.21-0.88)$ & $0.02^{*}$ \\
\hline No & $86(83.5$ & $236(84.0)$ & 1 & 1 & 1 & 1 \\
\hline \multicolumn{7}{|c|}{ Close contact with known TB } \\
\hline Yes & $33(32.0)$ & $91(32.4)$ & $2.63(2.24-4.46)$ & $0.02^{*}$ & $3.42(2.24-4.50)$ & $0.01^{*}$ \\
\hline No & $70(68.0)$ & 190(67.6) & 1 & 1 & 1 & 1 \\
\hline \multicolumn{7}{|c|}{ History of imprisonment } \\
\hline Yes & 10(9.7) & 28(9.9) & $1.05(0.22-1.16)$ & 0.108 & $1.05(0.22-1.16)$ & 0.108 \\
\hline No & $93(90.3$ & 253(90.1) & 1 & 1 & 1 & 1 \\
\hline \multicolumn{7}{|l|}{ Frequent alcohol } \\
\hline Yes & 11(10.8) & $31(11.0)$ & $1.24(0.65-2.38)$ & 0.312 & $1.24(0.65-2.38)$ & 0.211 \\
\hline No & $92(89.2)$ & 250(89.0) & 1 & 1 & 1 & 1 \\
\hline \multicolumn{7}{|c|}{ Status of HIV antibody test } \\
\hline Yes & $8(7.8)$ & $21(7.5)$ & $2.91(1.06-3.51)$ & $0.02^{*}$ & $2.01(1.07-3.52)$ & $0.01^{*}$ \\
\hline No & 95(92.2) & $260(92.5)$ & 1 & 1 & 1 & 1 \\
\hline
\end{tabular}


MTB, but limited data were available in the study area. In our study, the overall prevalence of MTB was $26.8 \%$. In the current study, the prevalence of MTB was in line with previous reports from Hawasa 30.5\%) [18], Debremarkos (23.1\%) [19] and Nigeria, 22.9\% [20]. However, our finding was lower than studies conducted in Congo, 79.1\% [21] and Togo, 57\% [22]. In contrast to our study, however, the study conducted in Amhara, 11\% [23], Addis Ababa, 12.5\% [24], South Africa, 13\% [25] and Korea, $13.8 \%$ [26], Uganda 5.5\% [27], and Oromia region, 3.8\% [28] were lower than our current study. The difference might be due to variation in methodological techniques (culture vs. Xpert), study participants, study period, sample size, geography and TB control and prevention practices.

In this study, males were more likely to have MTB when compared to female patients. Similarly, studies conducted in Philippines [29], North Sudan [30] and elsewhere [19] reported as females were less likely to have MTB compared to males. The explanation for enhanced MTB in males could be probably due to males are mainly involved in outdoor activities and have more frequent contact with TB patients while females usually stay at home. In this study, there is no association between participants' age groups, residence and marital status.

This is similar with studies conducted in different areas that reported no association between age, residence and marital status and TB infection [31-34]. However, different studies reported higher prevalence of MTB in age groups ranging from 16 to 34 years $[35,36]$.

In our study, TB patients who had no educational background (illiterate) were found to be more likely to develop TB compared to patients who had an educational background. Similar to our study, different studies reported that being illiterate was one of the contributing factors to develop TB [37-40]. Most of the communities living in developing countries were illiterate and have a low level of knowledge on TB. Low level of knowledge on TB can lead to complications and worse health outcomes, increasing the transmission and delaying health seeking behavior, lack of adherence, resulting in multidrug resistance, treatment failure, and disease complications and death $[41,42]$. Thus, health programmers and stakeholder should give special attention and design a package in the national TB control program that addresses such areas where may people were lack awareness.

In the current study, smoking and khat chewing were found to be contributing factors for developing TB. This is in agreement with studies conducted in different areas which reported being smokers and khat chewers were risk factors for developing TB [38, 43-45]. Smoking damages the lungs and impacts the body's immune system, making smokers more susceptible to TB infection. The occurrence of TB has been directly associated with impairment of the immune response and multiple defects in immune cells [46]. Smoking also results in histological changes in the lower respiratory tract, including peri-bronchial inflammation, fibrosis, vascular intimal thickening, and destruction of alveoli. This can be resulted in abnormal function of epithelial and damaged ciliary clearance of inhaled substances. Mechanical disruption of cilia function and hormonal effects could also appear secondarily to smoking [47-50]. Khat chewing is also associated with immune modulations that facilitates for TB development [51].

In our study, the occurrence of TB was less in those study participants who were vaccinated for BCG. This is in line with other studies conducted in different areas where lack of vaccination for BCG is a significant contributing factor for developing TB [39, 40, 52, 53]. The $B C G$ vaccine is one of the most widely used of all current vaccines for neonates and infants in countries where it is part of the national childhood immunization program. BCG vaccination may be considered for health care workers who are employed in settings in which the likelihood of transmission and subsequent infection with $M$. tuberculosis strains resistant to isoniazid and rifampin is high. The protective efficacy of BCG for pulmonary TB in adults is uncertain $[54,55]$.

Our data demonstrate that close contact with known TB is one of the risk factors for the transmission and development of TB. Close contacts of patients with infectious tuberculosis are at increased risk of developing $M$. tuberculosis infection and disease $[56,57]$. The prevalence of pulmonary TB in close contact was reported to be highest among many risk groups where there is an overcrowded population like homeless people, injection drug users, and prisoner live [58, 59]. Close contact is also one of the common risk factors for progression from latent TB infection to active disease [60]. Therefore, early diagnosis, isolation of known pulmonary $\mathrm{TB}$ and treatment is important to reduce and control the transmission of the disease.

In this study, HIV-positive patients were found to be contributing factors for the development of TB. HIV kills our immune system cells that help the body fight infections and diseases and facilitate for the development of TB. HIV and TB are considered as the double burden diseases of the world. According to WHO reports, there were 1.5 million deaths attributed to $\mathrm{TB}$ out of which $26 \%$ were due to HIV-associated TB [61, 62]. In underdeveloped countries, the prevalence of HIV is high and 
this resulted in an increased number of $\mathrm{TB}$ infections [63]. Of the 1.2 million TB-HIV cases worldwide, Africa accounts about $74 \%$ of the cases [63]. In Ethiopia, 4 in 100 people died due to TB-HIV co-infection and the incidence of multidrug-resistant tuberculosis (MDRTB) was estimated to be 5.8 per 1000 people (64). In this study, being in prison and consumption of alcohol had no association with the development of TB.

\section{Limitations of the study}

This study included a small sample size which may not be representative of a total population. Antimicrobial susceptibility tests were not assessed due to lack of infrastructure.

\section{Conclusion}

The overall prevalence of MTB in this study was 26.8 . Males were more likely to develop TB than females. Study participants who were illiterate were more likely to develop TB than the educated ones. Study participants who were cigarette smokers, khat chewers, BCG vaccination, close contact with known $\mathrm{TB}$ and being positive for HIV were more likely to develop TB. As the prevalence of MTB was still high despite the implementation of national and international TB control strategies and no significant reduction from time to time; health programmers and stakeholders should give special attention on early case detection and management of TB to strengthen and an appropriate control and prevention methods to reduce the emergence and increasing of MTB cases and design a package in the national TB monitoring and evaluation of the program that addresses such areas where thousands of people are live in overcrowded area.

\section{Abbreviations \\ AFB: Acid-fast bacilli; AOR: Adjusted odds ratio; COR: Crude odds ratio; EPTB: Extra-pulmonary tuberculosis; HIV: Human immunodeficiency virus; MDR: Multi-drug resistance; MDR-TB: Multidrug resistant tuberculosis; MTB: Myco- bacterium tuberculosis; PTB: Pulmonary tuberculosis; RIF: Rifampicin; RR-TB: Rifampicin-resistant tuberculosis; RR-MTB: Rifampicin-resistant Mycobacterium tuberculosis; SSA: Sub-Saharan Africa; TB: Tuberculosis; WHO: World Health Organization.}

\section{Acknowledgements}

The authors would like to acknowledge Dilla University Research and Dissemination Office for funding this research, Dilla University referral hospital medical director and all staff of department of medical laboratory for their co-operation in allowing the researchers to access the records and extract the data.

\section{Authors' contributions}

All authors made a significant contribution to the work reported, whether that is in the conception, study design, execution, acquisition of data, analysis and interpretation, or in all these areas; took part in drafting, revising, or critically reviewing the article; gave final approval of the version to be published; have agreed on the journal to which the article has been submitted; and agree to be accountable for all aspects of the work. All authors read and approved the final manuscript.
Funding

This study was funded by Dilla University Research and Dissemination Office.

\section{Data availability}

All data relevant to the study are included in the article and other raw dataset used for analysis during the current study are available from the corresponding author on reasonable request.

\section{Declarations}

\section{Ethics approval and consent to participate}

The protocol for patient recruitment and participation in the study followed the principles of the Declaration of Helsinki and was approved by the Dilla University Health Research Ethics Review Committee under the protocol unique number 005/21-01. In the current study, socio-demographic and clinical data of TB suspected patients were collected retrospectively from medical records after getting permission to conduct the study from Dilla University referral hospital medical director and respective departments. Informed consent was not applicable for study participants since the study was retrospective and we have used the clinical data obtained from routine medical services. Strict confidentiality was maintained by removing all patient identifiers and only code numbers were used throughout the study.

\section{Consent for publication}

Not applicable.

\section{Competing interests}

The authors declare that there are no competing interests.

\section{Author details}

${ }^{1}$ Department of Medical Laboratory Sciences, Health Science and Medical College, Dilla University, Dilla, Ethiopia. ${ }^{2}$ Department of Medical Laboratory Sciences, Immunology Unit, Health Science and Medical College, Dilla University, Dilla, Ethiopia.

Received: 8 December 2021 Accepted: 1 February 2022

Published online: 12 February 2022

\section{References}

1. Khan M, Raja Z, Ahmed H, Rauf A. A pattern of tuberculosis infection an overview. Pak J Biotechnol. 2019;16(3):153-61.

2. Organization WH. Global status report on alcohol and health 2018. Geneva: World Health Organization; 2019.

3. Organization WH. Tracking universal health coverage: first global monitoring report. Geneva: World Health Organization; 2015.

4. Organization WH. Global tuberculosis report 2013. Geneva: World Health Organization; 2013

5. Organization WH. World Health Organization global tuberculosis report 2017 (WHO/HTM/TB/2017.23). World Health Organization, Geneva, Switzerland. 2017. http://apps.who.int/iris/bitstream/10665/191102/1/97892 41565059_eng.pdf.

6. Zaman K. Tuberculosis: a global health problem. J Health Popul Nutr. 2010;28(2):111.

7. Korenromp EL, Glaziou P, Fitzpatrick C, Floyd K, Hosseini M, Raviglione M, et al. Implementing the global plan to stop TB, 2011-2015-optimizing allocations and the global fund's contribution: a scenario projections study. PLOS ONE. 2012;7(6):e38816.

8. Uplekar M, Weil D, Lonnroth K, Jaramillo E, Lienhardt C, Dias H. WHO's Global. TB Programme. WHO's new end TB strategy. Lancet. 2015;385(9979):1799-801.

9. Nimbarte S, Deshmukh P, Mehendale A, Garg B. Effect of duration of cough ( $\geq 3$ weeks vs $\geq 2$ weeks) on yield of sputum positive tuberculosis cases and laboratory load. Online J Health Allied Sci. 2009;8(2):7.

10. Singh J, Sankar MM, Kumar S, Gopinath K, Singh N, Mani K, et al. Incidence and prevalence of tuberculosis among household contacts of pulmonary tuberculosis patients in a peri-urban population of South Delhi, India. PLoS ONE. 2013;8(7):e699730. 
11. Adane A, Damena M, Weldegebreal F, Mohammed H. Prevalence and associated factors of tuberculosis among adult household contacts of smear positive pulmonary tuberculosis patients treated in public health facilities of Haramaya district, Oromia region, eastern Ethiopia. Tuberc Res Treat. 2020. https://doi.org/10.1155/2020/6738532.

12. Omotowo B, Ekwueme O, Aghaji M. M. Tuberculosis control mechanisms and contact tracing: knowledge and practice among TB patients at DOT centres is Southeast Nigeria. Sci Rep. 2012;9:1.

13. Lienhardt C, Fielding K, Sillah J, Tunkara A, Donkor S, Manneh K, et al. Risk factors for tuberculosis infection in sub-Saharan Africa: a contact study in the Gambia. Am J Respir Crit Care Med. 2003;168(4):448-55.

14. Davies P. Risk factors for tuberculosis. Monaldi Arch Chest Dis. 2005;63(1):37-46

15. Coker R, McKee M, Atun R, Dimitrova B, Dodonova E, Kuznetsov S, et al. Risk factors for pulmonary tuberculosis in Russia: case-control study. BMJ. 2006;332(7533):85-7.

16. bālaśelțān EYs, Macro O. Ethiopia demographic and health survey. Addis Ababa: Central statistical authority; 2005. p. 2006

17. FMoHo E. National consolidated guidelines for comprehensive HIV prevention, care and treatment. Geneva: World Health Organization; 2020.

18. Andarge DB, Anticho TL, Jara GM, Ali MM. Prevalence of Mycobacterium tuberculosis infection and rifampicin resistance among presumptive tuberculosis cases visiting tuberculosis clinic of Adare general hospital South Ethiopia. SAGE Open Med. 2021;9:20503121211045540.

19. Mulu W, Abera B, Yimer M, Hailu T, Ayele H, Abate D. Rifampicinresistance pattern of Mycobacterium tuberculosis and associated factors among presumptive tuberculosis patients referred to Debre Markos referral hospital, Ethiopia: a cross-sectional study. BMC Res Notes. 2017;10(1):1-8.

20. Tahiri L, Azzouzi H, Squalli G, Abourazzak F, Harzy T. Celiac disease causing severe osteomalacia: an association still present in Morocco! Pan Afr Med J. 2014;19:43.

21. Farra A, Manirakiza A, Yambiyo BM, Zandanga G, Lokoti B, Berlioz-Arthaud A, et al editors. Surveillance of rifampicin resistance with GeneXpert MTB/ RIF in the national reference laboratory for tuberculosis at the Institut Pasteur in Bangui, 2015-2017 Open forum infectious diseases. Oxford: Oxford University Press US; 2019.

22. Dagnra A, Mlaga K, Adjoh K, Kadanga E, Disse K, Adekambi T. Prevalence of multidrug-resistant tuberculosis cases among HIV-positive and HIV-negative patients eligible for retreatment regimen in Togo using GeneXpert MTB/RIF. New Microb New Infect. 2015;8:24-7.

23. Wasihun AG, Hailu GG, Dejene TA. Prevalence of Mycobacterium tuberculosis (Rifampicin-Resistant MTB) and associated risk actors among pulmonary presumptive TB patients in eastern amhara, Ethiopia: 2015-2019. Infect Dis Ther. 2021;10(3):1299-308.

24. Desta K, Asrat D, Lemma E, Gebeyehu M, Feleke B. Drug susceptibility of Mycobacterium tuberculosis isolates from smear negative pulmonary tuberculosis patients, Addis Ababa, Ethiopia. Ethiop J Health Dev. 2008. https://doi.org/10.4314/ejhd.v22i2.10075.

25. Nicol MP, Workman L, Isaacs W, Munro J, Black F, Eley B, et al. Accuracy of the Xpert MTB/RIF test for the diagnosis of pulmonary tuberculosis in children admitted to hospital in Cape Town, South Africa: a descriptive study. Lancet Infect Dis. 2011;11(11):819-24.

26. Kim C-H, Hyun IG, Hwang YI, Kim D-G, Lee CY, Lee MG, et al. Identification of Mycobacterium tuberculosis and rifampin resistance in clinical specimens using the Xpert MTB/RIF assay. Ann Clin Lab Sci. 2015;45(1):32-8.

27. Yin L, Qin G, Qian H-Z, Zhu Y, Hu W, Zhang L, et al. Continued spread of HIV among injecting drug users in southern Sichuan province China. Harm Reduct J. 2007:4(1):1-7.

28. Hamusse SD, Teshome D, Hussen MS, Demissie M, Lindtjørn B. Primary and secondary anti-tuberculosis drug resistance in Hitossa district of Arsi zone, Oromia regional state Central Ethiopia. BMC Public Health. 2016:16(1):1-10.

29. Know K, Yadav R, Denholm J, Sawyer S, Graham S. Tuberculosis among children, adolescents and young adults in the Philippines: a surveillance report. West Pac Surveill Response J. 2018;9(4):16.

30. Rahman A, Sahrin M, Afrin S, Earley K, Ahmed S, Rahman SM, et al. Comparison of Xpert MTB/RIF assay and GenoType MTBDR plus DNA probes for detection of mutations associated with rifampicin resistance in Mycobacterium tuberculosis. PLoS ONE. 2016;11(4):2694.
31. Abebe G, Abdissa K, Abdissa A, Apers L, Agonafir M, de Jong BC, et al. Relatively low primary drug resistant tuberculosis in southwestern Ethiopia. BMC Res Notes. 2012;5(1):1-6.

32. Sa'ed HZ, Al-Jabi SW. Mapping the situation of research on coronavirus disease-19 (COVID-19) a preliminary bibliometric analysis during the early stage of the outbreak. BMC Infect Dis. 2020;20(1):1-8.

33. Hordofa GM. Multi-drug resistant Mycobacterium tuberculosis and. BMC Res Notes. 2012;5(462):266.

34. Odum EP, Udi EO. Evaluation of cardiovascular risk factors in patients with chronic kidney disease. Port Harcourt Med J. 2017;11(2):60.

35. Hordofa MW, Adela TB. Prevalence of Refampcin mono resistant Mycobacterium tuberculosis among suspected cases attending at Yirgalem hospital. Clin Med Res. 2015;4(3):75-8.

36. Adane K, Ameni G, Bekele S, Abebe M, Aseffa A. Prevalence and drug resistance profile of Mycobacterium tuberculosis isolated from pulmonary tuberculosis patients attending two public hospitals in East Gojjam zone, northwest Ethiopia. BMC Public Health. 2015;15(1):1-8.

37. Bhat J, Rao V, Sharma R, Muniyandi M, Yadav R, Bhondley MK. Investigation of the risk factors for pulmonary tuberculosis: a case-control study among Saharia tribe in Gwalior district, Madhya Pradesh, India. Indian J Med Res. 2017;146(1):97.

38. Berhe G, Enquselassie F, Aseffa A. Assessment of risk factors for development of active pulmonary tuberculosis in northern part of Ethiopia: a matched case control study. Ethiop Med J. 2013;51(4):227-37.

39. Kehinde A, Baba A, Bakare R, Ige O, Gbadeyanka C, Salako A. Risk factors for pulmonary tuberculosis among health-care workers in Ibadan, Nigeria. Afr J Med Med Sci. 2010;39(2):105-12.

40. Shimeles E, Enquselassie F, Aseffa A, Tilahun M, Mekonen A, Wondimagegn $\mathrm{G}$, et al. Risk factors for tuberculosis: a case-control study in Addis Ababa, Ethiopia. PLoS ONE. 2019;14(4):4235.

41. Gelaw SM. Socioeconomic factors associated with knowledge on tuberculosis among adults in Ethiopia. Tuberc Res Treat. 2016. https://doi.org/ 10.1155/2016/6207457.

42. Taylor G. Tuberculosis: making progress to stop tuberculosis. Canada Commun Dis Rep. 2014;40(6):97.

43. Tulu B, Dida N, Kassa Y, Taye B. Smear positive pulmonary tuberculosis and its risk factors among tuberculosis suspect in South East Ethiopia; a hospital based cross-sectional study. BMC Res Notes. 2014;7(1):1-6.

44. Bigwan E, Ohaeri M, David E, Wakjissa FD, Sheyin Z. Some risk factors associated with acid-alcohol-fast bacilli in patients with suspected pulmonary tuberculosis in jos, central Nigeria. Afr J Infect Dis. 2014;8(2):27-30.

45. Alemu YM, Awoke W, Wilder-Smith A. Determinants for tuberculosis in HIV-infected adults in Northwest Ethiopia: a multicentre case-control study. BMJ Open. 2016;6(4):9058.

46. Altet M, Alcaide J, Plans P, Taberner J, Salto E, Folguera L, et al. Passive smoking and risk of pulmonary tuberculosis in children immediately following infection a case-control study. Tuber Lung Dis. 1996;77(6):537-44.

47. Buskin SE, Gale JL, Weiss NS, Nolan CM. Tuberculosis risk factors in adults in king county, Washington, 1988 through 1990. Am J Public Health. 1994;84(11):1750-6.

48. Sopori ML, Kozak W. Immunomodulatory effects of cigarette smoke. J Neuroimmunol. 1998;83(1-2):148-56.

49. Den Boon S, Van Lill S, Borgdorff M, Verver S, Bateman E, Lombard C, et al. Association between smoking and tuberculosis infection: a population survey in a high tuberculosis incidence area. Thorax. 2005;60(7):555-7.

50. Leung C, Yew W, Chan C, Tam C, Lam C, Chang K, et al. Smoking and tuberculosis in Hong Kong. Int J Tuberc Lung Dis. 2003;7(10):980-6.

51. Alvi A, Rizwan M, Sunosi RA, Jerah ABA. Does khat chewing increases the risk of Mycobacterium tuberculosis infection by macrophage immune modulation? Med Hypotheses. 2014;82(6):667-9.

52. Son M, Park YS, Jung MH, Kang JH, Choi UY. Risk factors for latent tuberculosis infection in children in South Korea. Postgrad Med. 2018;130(7):637-43.

53. Adesokan H, Cadmus E, Adeyemi W, Lawal O, Ogunlade C, Osman E, et al. Prevalence of previously undetected tuberculosis and underlying risk factors for transmission in a prison setting in Ibadan, south-western Nigeria. Afr J Med Med Sci. 2014;43(Suppl 1):45.

54. Whelan KT, Pathan AA, Sander CR, Fletcher HA, Poulton I, Alder NC, et al. Safety and immunogenicity of boosting BCG vaccinated subjects with BCG: comparison with boosting with a new TB vaccine, MVA85A. PLoS ONE. 2009;4(6):e5934. 
55. Liu J, Tran V, Leung AS, Alexander DC, Zhu B. BCG vaccines: their mechanisms of attenuation and impact on safety and protective efficacy. Hum Vaccin. 2009;5(2):70-8

56. Trunz BB, Fine P, Dye C. Effect of BCG vaccination on childhood tuberculous meningitis and miliary tuberculosis worldwide: a meta-analysis and assessment of cost-effectiveness. Lancet. 2006;367(9517):1173-80.

57. Reichler MR, Reves R, Bur S, Thompson V, Mangura BT, Ford J, et al. Evaluation of investigations conducted to detect and prevent transmission of tuberculosis. JAMA. 2002;287(8):991-5.

58. Organization WH. The global plan to stop TB, 2006-2015: summary. Wkly Epidemiol Rec (Relevé épidémiologique Hebd). 2006;81 (09):86-8.

59. Organization WH. Global tuberculosis control: key findings from the December 2009 WHO report. Wkly Epidemiol Rec (Relevé épidémiologique hebd). 2010;85(09):69-79.

60. Horsburgh C, Rubin E. Supplement to: latent tuberculosis infection in the United States. N Engl J Med. 2011;364(15):1441-8.

61. Maheu-Giroux M, Vesga JF, Diabaté S, Alary M, Baral S, Diouf D, et al. Population-level impact of an accelerated HIV response plan to reach the UNAIDS 90-90-90 target in Côte d'Ivoire: insights from mathematical modeling. PLoS Med. 2017;14(6):e1002321.

62. Ntoumi F, Kaleebu P, Macete E, Mfinanga S, Chakaya J, Yeboah-Manu D, et al. Taking forward the world TB day 2016 theme 'unite to end tuberculosis' for the WHO Africa region. Int J Infect Dis. 2016;46:34-7.

63. Nachega JB, Chaisson RE. Tuberculosis drug resistance: a global threat. Clin Infect Dis. 2003;36(Supplement_1):S24-30.

64. Tiberi S, Petersen E, Maeurer M, Ntoumi F, Yeboa-Manu D, Mwaba P, et al. Taking forward the stop TB partnership and world health organization joint theme for world TB day march 24th 2018 - "wanted: leaders for a TB-free world. You can make history. End TB." Int J Infect Dis. 2018;68:122-4.

\section{Publisher's Note}

Springer Nature remains neutral with regard to jurisdictional claims in published maps and institutional affiliations.

- fast, convenient online submission

- thorough peer review by experienced researchers in your field

- rapid publication on acceptance

- support for research data, including large and complex data types

- gold Open Access which fosters wider collaboration and increased citations

- maximum visibility for your research: over 100M website views per year

At BMC, research is always in progress.

Learn more biomedcentral.com/submissions 